\title{
Statistical Model for Assessing the Impact of Digitalization on the Development of Municipal Formations in a Region
}

\author{
Burtseva T.A. ${ }^{1}$ Aleshnikova V.I. ${ }^{2}$ Beregovskaya T.A..$^{2 *}$ \\ ${ }^{1}$ Department of Statistics, RTU MIREA, Moscow, 119454, Russia \\ ${ }^{2}$ Marketing Department, State University of Management, Moscow, 109542 Russia \\ *Corresponding author. Email:ta_beregovskay@guu.ru
}

\begin{abstract}
The relevance of the study is determined by current trends in the development of world economy, Russian economy and the development issues in digital economy of federal subjects and municipal formations of Russia. It is challenging to assess the impact of digital environment on federal subjects and municipal formations and to make substantiated conclusions about the effectiveness of the national program "Digital Economy of the Russian Federation" due to absence of international standards in the field of statistical measurement of digital economy and low level of development of the national methodology for collecting, processing and analyzing statistical information about the state of digital economy.

This article offers a solution to the scientific issue of creating integrated statistical measures of the influence of digital environment on the socio-economic development of federal subjects and municipal formations amid limited information resources. The article substantiates the use of the dynamic standard method as a solution for the issue. First, it enables a comprehensive accumulation of directly incommensurate figures; secondly, it ensures the possibility of an integrated assessment (an integrated measure that characterizes the system based on the property of interest as a whole while taking into account the interconnections of the elements within it); thirdly, it has a high informational capacity as it enables dynamic integrated assessments based on a large number of indicators amidst short period of observation. Two observation periods and three periods for representing its relative growth rate by indicators and groups (factors) of indicators are sufficient to create an integrated assessment using this method.

The results of the study are: a target and evaluative standardization model of the impact of digital environment on the socio-economic development of federal subjects and municipal formations; a system of monitoring indicators of socio-economic development sustainability of municipal districts and city districts; testing of the evaluative standardization model illustrated by the case of municipal districts and city districts of Kaluga Oblast under the development of digital economy.
\end{abstract}

Keywords: digital economy, digital inequality, target model, evaluative standardization model, socioeconomic development sustainability, federal subject, municipal formation

\section{INTRODUCTION}

Currently Russia is among the top ten countries leading in digital economy development (according to the Digital Society Index [1]). However, experts note its unevenness in its varying sectors and in different federal subjects of the Russian Federation, as well as within them. In 2017 the figures showing the rates of Internet connection in the federal subjects of Russia varied by a factor of $2.8(93.3 \%$ - Yamalo-Nenets Autonomous Okrug; 32.8\% Chechen Republic). The difference of the federal subjects of Russia in the level of digital economy development in business sector reached the factor of 1.5 in 2018 (for reference, in 2004 the federal subjects differed 5 times in the proportion of organizations using the Internet) [2]. Among the leading implementers of digitalization are the financial sector (Sberbank of Russia), transportation sector (Russian Railways), and communications sector (Russian Post). Industrial, social services, and public administration branches are at the average level of digitalization. Agricultural and educational sectors delay progress. [3]. We believe that among the main issues of digital economy development in Russia's federal subjects, such as different rates of growth, lack of innovation, information security and qualified experts in digital economy, particular attention should be paid to developing a methodology for measuring the level of digital development and inequality, the impact of digital technologies on national and regional 
economies. The relevance of creating such a monitoring system is justified by the need to assess the results of the national project "Digital Economy".

The authors believe that solving the problem of measuring and evaluating the impact of digital environment on the socio-economic development of federal subjects and municipal formations will contribute to rapid decisionmaking in order to even out the noticeable differences in federal subjects and municipal formations and increase the sustainability of their development.

\section{LITERATURE REVIEW}

A significant contribution to the development of the theoretical foundations of digital economy was made by $\mathrm{N}$. Negroponte [4], D. Tapscott [5]. The study by D. Hamilton examines the transatlantic aspect of the digital economy [6]. The issues of digital economy became of more interest for researchers in 2017 due to the implementation of the program "Digital Economy of the Russian Federation" [7]. The phenomenon of "digital economy" and "digital inequality" is studied in the work of M. Yu. Arkhipova, V. P. Sirotin [8]. Regional problems of digitalization in Russia are reflected in the works $[9,10,11,12,13,14]$. One of the approaches to statistical research of federal subjects' implementing digitalization process was suggested by A. Tikhonova, N. Melnikova, N. Vishnevskaya [15].

\section{RESEARCH METHODS}

The essence of the dynamic standard method is forming groups of indicators characterizing the purpose and, to the greatest extent, reflecting the real state of the object of research in dynamics. The above-indicated groups are formed in accordance with an objective (e.g., maximizing a company's profit, increasing the cost of equity, increasing regional investment appeal). The quantitative composition of the indicators should be no lower than the established (no less than 6 and no more than 25). The dynamic standard method is the procedure of selection and arrangement of economic indicators.

The main idea of the method belongs to I. M. Syroezhin [16]. The core concept is that statistically incommensurate indicators are dynamically commensurate. There are examples of application of the dynamic standard method in modern scientific works and publications [17, 18, 19, 20, 21,22, 23].

I. M. Syroezhin (1980) noted that incommensurate static characteristics of the national economy are commensurate in dynamics. The proposed dynamic standard is organized by rates (coefficients, indices) of growth (base or chain) of a set (system) of indicators in such a way, that long-term maintaining of the indicators in the order set by the dynamic standard will maximize the integrated assessment. The indicators are ranked by performance by assigning ranks to them. If not all indicators are possible to link strictly in order, a preference graph and/or a corresponding matrix of preferences serves as a form of the dynamic standard. In this case the integrated measure has the form of a standardization model. The quantitative level of the integrated measure (integrated assessment) in this case is the ratio of the number of performed correlations between rates (indices) of growth of actual indicators characterizing the specific object in study, to the number of set correlations in a standardization model. Accordingly, the resulting quantitative levels vary from 0 to 1 , the closer the value is to 1 , the higher the quantitative level of the valuation is.

The algorithm for constructing standardization models is described in detail in the work of T. A. Burtseva, N. Y. Chausow [24]. The standardization model differs from the matrix of preferences, and its indicators are categorized by the transitional property, which makes obtaining of a single measurement possible in all cases.

The advantages of this particular method over other methods of creating an integrated measure, such as multidimensional average, are the following:

First, it enables a comprehensive accumulation of directly incommensurate figures, reflecting different aspects of the economic system functioning, figures being presented in ordinal scale of measurement;

secondly, it ensures the possibility of an integrated assessment (an integrated measure that characterizes the system based on the property of interest as a whole while taking into account the interconnections of the elements within it);

thirdly, in the standardization model each figure retains its own role and there is no effect of "positive" and "negative" changes, captured by different indicators, cancelling one another;

fourthly, it has a high informational capacity as it enables dynamic integrated assessments based on a large number of indicators amidst short period of observation, i.e. two periods are sufficient to make an assessment and three periods to represent its relative growth rate by indicators and groups (factors) of indicators.

\section{RESULTS}

The authors propose a methodological approach to the creation of an evaluative standardization model of the socio-economic development sustainability of a municipal formation in digital economy.

It is based on a system of indicators of socio-economic development of a municipal formation in digital economy and a target model, these being grounded on the informational resources of the Russian Federal State Statistics Service or Rosstat, and Rostelecom PJSC (Rosstat's official partner for digitalization of statistics) (table 1, figure 1 ).

The evaluative standardization model enables calculating quantitative levels of sustainability of socio-economic development of a municipal formation in digital economy and representation of their growth by five factors (quality of life of the population, comfortable living environment, 
The source of information for calculating the quantitative levels of socio-economic development sustainability of a municipal formation under modernization of the digital environment was the growth indices of the indicators presented in table 1 . modernized for new-generation personal computers by $\mathrm{V}$. A. Burtsev. The formulas used to calculate quantitative levels, their factor increments, and the process of creating evaluative standardization models are described in detail in the work of T. A. Burtseva, N. Y. Chausow [24].

Table 1 The system of indicators of socio-economic development of the municipal formation in digital economy

\begin{tabular}{|c|c|c|}
\hline Factor & Goal & Indicators \\
\hline \multirow{5}{*}{ Quality of life } & \multirow{3}{*}{ Increase in life expectancy } & Average annual population \\
\hline & & Life expectancy of the population as a whole \\
\hline & & Number of children of pre-school age \\
\hline & \multirow{2}{*}{$\begin{array}{c}\text { Increase in availability of } \\
\text { high-tech medical care and } \\
\text { diagnostics }\end{array}$} & Number of ill people \\
\hline & & Number of elderly citizens \\
\hline \multirow{5}{*}{$\begin{array}{l}\text { Comfortable living } \\
\text { environment }\end{array}$} & \multirow{2}{*}{$\begin{array}{l}\text { Increase in the availability of } \\
\text { comfortable housing }\end{array}$} & $\begin{array}{c}\text { Housing availability, square meters of total area per } \\
\text { inhabitant }\end{array}$ \\
\hline & & Share of dilapidated housing \\
\hline & \multirow[b]{2}{*}{$\begin{array}{l}\text { Increase in the quality of } \\
\text { social services }\end{array}$} & Number of children in pre-school education \\
\hline & & $\begin{array}{c}\begin{array}{c}\text { Number of elderly and disabled people served at } \\
\text { home }\end{array} \\
\end{array}$ \\
\hline & $\begin{array}{l}\text { Increase in the quality of } \\
\text { environment }\end{array}$ & Emissions of pollutants into the air \\
\hline \multirow{3}{*}{ Budgetary security } & \multirow{2}{*}{ Increase in budgetary security } & Budget revenues \\
\hline & & Budget expenditures \\
\hline & $\begin{array}{l}\text { Growth of real income of the } \\
\text { population }\end{array}$ & Real income of the population \\
\hline \multirow{5}{*}{ Innovative economy } & \multirow{4}{*}{$\begin{array}{l}\text { Growth of scientific and } \\
\text { technical potential }\end{array}$} & Amount of innovative products, works, and services \\
\hline & & Amount of products, works, and services \\
\hline & & $\begin{array}{l}\text { Number of organizations that implemented } \\
\text { innovations in the reported year }\end{array}$ \\
\hline & & Number of registered organizations \\
\hline & $\begin{array}{l}\text { Increase in employment in } \\
\text { high-tech industries }\end{array}$ & Number of high-performance jobs \\
\hline \multirow{3}{*}{ Digital environment } & $\begin{array}{l}\text { Increase in digital literacy of } \\
\text { the population }\end{array}$ & Population using the Internet at the age of $15-72$ \\
\hline & \multirow{2}{*}{$\begin{array}{l}\text { Electronic business } \\
\text { development }\end{array}$} & Number of organizations that have a website \\
\hline & & Number of organizations that have servers \\
\hline
\end{tabular}




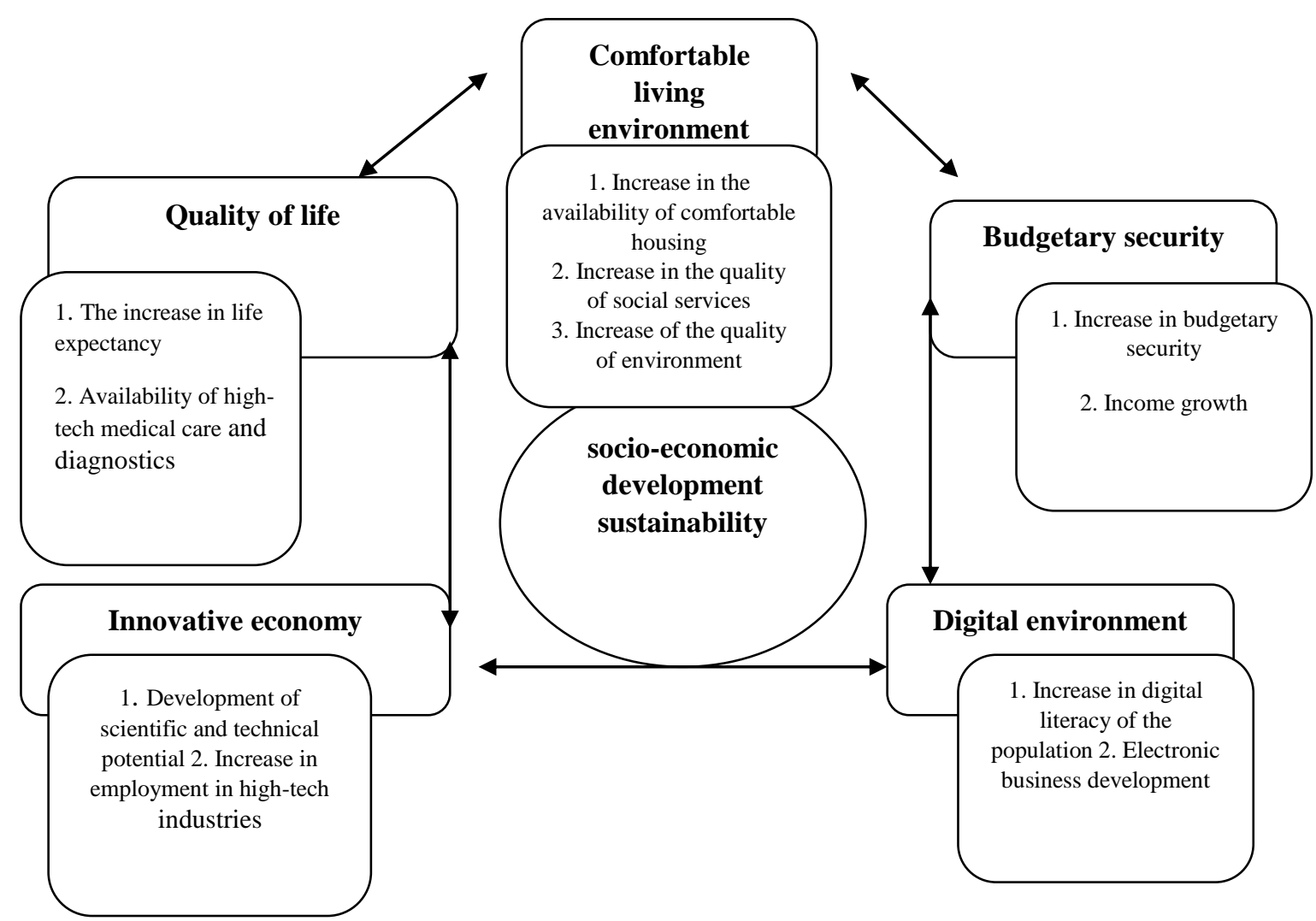

Figure 1 The target model of socio-economic development of a municipal formation in digital economy

The choice of the time period for analysis is attributed to the beginning of the implementation of the program "Digital Economy of the Russian Federation" [7]. These indices were calculated for municipal districts and city districts of Kaluga Oblast for the years of 2016-2017 by 2015 in a comparable estimate.

The table 2 shows the quantitative levels of socioeconomic development sustainability of municipal districts, city districts and Kaluga Oblast for 2016-2017 compared to 2015 , and the rankings obtained on the basis of the above-mentioned levels. The quantitative level varies from 0 to 1 . It is equal to 1 , if all ratios of growth indices of indicators, pairwise established by the standard, are actually met in the evaluative standardization model; it is equal to 0 , if the actual order of indicators is completely opposite to the standard order of indicators in the model. The closer the quantitative level is to 1 , the greater is the share of standard ratios between indicators implemented in reality, and the higher is the level of socio-economic development sustainability of the municipal formation. Table 2 also shows the absolute growth rate. A negative rate means a negative trend; a positive rate shows a positive trend.

The conclusions based on the results of monitoring the socio-economic development sustainability of municipal districts and city districts of Kaluga Oblast:
- Five municipal districts of the region have significantly lowered the estimate (Dzerzhinskiy, Medynskiy, Peremishlyanskiy, Spas-Demensky and Baryatinsky).

- In 2017 Peremyshlsky District's rank dropped from 1 to 24, Medynsky District's rank from 5-6 to 24 respectively.

- Zhukovsky, Ulyanovsky, Kuibyshevsky, Iznoskovsky, Meshchovsky, Duminichesky Districts and the town of Obninsk have significantly improved their positions.

To find out the reasons the authors conducted a factor layout of the absolute growth rate of the quantitative levels of socio-economic development sustainability of municipal districts (Table 3).

\section{CONCLUSIONS}

The analysis using the evaluative standardization model allowed us to draw the following conclusions about the impact of the digital environment on the development of municipal formations:

- Inequality in the socio-economic development of the districts has decreased. In 2017 the districts of the region differed 2.5 times, compared to 3.8 in 2016. In those districts of the region where, along with other positive changes, the digital environment has improved, there is a significant increase in the socio-economic development sustainability. 
Table 2 Rankings of municipal districts and city districts of Kaluga oblast based on the socio-economic development sustainability for 2016-2017 compared to 2015

\begin{tabular}{|l|c|c|c|c|c|}
\hline \multicolumn{1}{|c|}{ District } & $\mathbf{2 0 1 6}$ & $\mathbf{2 0 1 7}$ & Absolute & \multicolumn{2}{c|}{ Ranking } \\
\cline { 4 - 6 } & & & $\mathbf{2 0 1 6}$ & $\mathbf{2 0 1 7}$ \\
\hline Zhukovsky District & 0.227273 & 0.909091 & 0.681818 & 27 & 1.5 \\
\hline Maloyaroslavetsky District & 0.636364 & 0.909091 & 0.272727 & 12 & 1.5 \\
\hline Obninsk & 0.636364 & 0.863636 & 0.227272 & 12 & 3.5 \\
\hline Ulyanovsky District & 0.5 & 0.863636 & 0.363636 & 23 & 3.5 \\
\hline Kirovsky District & 0.590909 & 0.818182 & 0.227273 & 18 & 5.5 \\
\hline Kuibyshevsky District & 0.454545 & 0.818182 & 0.363637 & 24.5 & 5.5 \\
\hline Lyudinovsky District & 0.681818 & 0.772727 & 0.090909 & 7.5 & 7 \\
\hline Borovsky District & 0.636364 & 0.727273 & 0.090909 & 12 & 9 \\
\hline Zhizdrinsky District & 0.818182 & 0.727273 & -0.09091 & 2.5 & 9 \\
\hline Meshchovsky District & 0.590909 & 0.727273 & 0.136364 & 18 & 9 \\
\hline Duminichesky District & 0.545455 & 0.681818 & 0.136363 & 21.5 & 13 \\
\hline Ferzikovsky District & 0.772727 & 0.681818 & -0.09091 & 4 & 13 \\
\hline Iznoskovsky District & 0.318182 & 0.681818 & 0.363636 & 26 & 13 \\
\hline Tarussky District & 0.727273 & 0.681818 & -0.04545 & 5.5 & 13 \\
\hline Yukhnovsky District & 0.590909 & 0.681818 & 0.090909 & 18 & 13 \\
\hline Kaluga & 0.636364 & 0.636364 & 0 & 12 & 16 \\
\hline Babyninsky District & 0.545455 & 0.590909 & 0.045454 & 21.5 & 17.5 \\
\hline Mosalsky District & 0.454545 & 0.590909 & 0.136364 & 24.5 & 17.5 \\
\hline Kaluga Oblast & $\mathbf{0 . 5 9 0 9 0 9}$ & $\mathbf{0 . 5 4 5 4 5 5}$ & $\mathbf{- 0 . 0 4 5 4 5}$ & $\mathbf{1 8}$ & $\mathbf{2 0 . 5}$ \\
\hline Kozelsky District & $\mathbf{0 . 5 9 0 9 0 9}$ & $\mathbf{0 . 5 4 5 4 5 5}$ & $\mathbf{- 0 . 0 4 5 4 5}$ & $\mathbf{1 8}$ & $\mathbf{2 0 . 5}$ \\
\hline Sukhinichsky District & $\mathbf{0 . 6 3 6 3 6 4}$ & $\mathbf{0 . 5 4 5 4 5 5}$ & $\mathbf{- 0 . 0 9 0 9 1}$ & $\mathbf{1 2}$ & $\mathbf{2 0 . 5}$ \\
\hline Khvastovichsky District & $\mathbf{0 . 8 1 8 1 8 2}$ & $\mathbf{0 . 5 4 5 4 5 5}$ & $\mathbf{- 0 . 2 7 2 7 3}$ & $\mathbf{2 . 5}$ & $\mathbf{2 0 . 5}$ \\
\hline Dzerzhinsky District & 0.636364 & 0.5 & -0.13636 & 12 & 24 \\
\hline Medynsky District & 0.727273 & 0.5 & -0.22727 & 5.5 & 24 \\
\hline Peremyshlsky District & 0.863636 & 0.5 & -0.36364 & 1 & 24 \\
\hline Spas-Demensky District & 0.636364 & 0.454545 & -0.18182 & 12 & 26 \\
\hline Baryatinsky District & 0.681818 & 0.363636 & -0.31818 & 7.5 & 27 \\
\hline
\end{tabular}

Table 3 Factor layout of the absolute growth rate of the quantitative level of socio-economic development sustainability in municipal districts and city districts of Kaluga oblast

\begin{tabular}{|c|c|c|c|c|c|}
\hline \multirow{2}{*}{ District } & \multicolumn{5}{|c|}{ Factor growth rates, 2017 compared to 2016 } \\
\cline { 2 - 6 } & $\begin{array}{c}\text { Quality of } \\
\text { life }\end{array}$ & $\begin{array}{c}\text { Comfortable } \\
\text { living } \\
\text { environment }\end{array}$ & $\begin{array}{c}\text { Budgetary } \\
\text { security }\end{array}$ & $\begin{array}{c}\text { Innovative } \\
\text { economy }\end{array}$ & $\begin{array}{c}\text { Digital } \\
\text { environmen } \\
\text { t }\end{array}$ \\
\hline Zhukovsky District & $\mathbf{1 3 0}$ & $\mathbf{5 0}$ & $\mathbf{1 0}$ & $\mathbf{6 0}$ & $\mathbf{4 0}$ \\
\hline Iznoskovsky District & $\mathbf{2 8 . 5 7}$ & $\mathbf{3 5 . 7 1}$ & $\mathbf{1 4 . 2 9}$ & $\mathbf{2 1 . 4 3}$ & $\mathbf{1 4 . 2 9}$ \\
\hline Kuibyshevsky District & 45 & 20 & 15 & -10 & 10 \\
\hline Ulyanovsky District & $\mathbf{4 0 . 9 1}$ & $\mathbf{1 3 . 6 4}$ & $\mathbf{4 . 5 5}$ & $\mathbf{9 . 0 9}$ & $\mathbf{4 . 5 5}$ \\
\hline Maloyaroslavetsky & 14.29 & 14.29 & -7.14 & 17.86 & 3.57 \\
\hline District & 15.38 & 23.08 & 3.85 & 0 & -3.85 \\
\hline Kirovsky District & $\mathbf{1 0 . 7 1}$ & $\mathbf{7 . 1 4}$ & $\mathbf{0}$ & $\mathbf{1 7 . 8 6}$ & $\mathbf{0}$ \\
\hline Obninsk & 5 & 30 & 10 & -25 & 10 \\
\hline Mosalsky District & 12.5 & -16.67 & 4.17 & 12.5 & 12.5 \\
\hline Duminichesky District & -19.23 & 19.23 & 7.69 & 11.54 & 3.85 \\
\hline Meshchovsky District & 19.23 & -7.69 & 11.54 & 11.54 & -7.69 \\
\hline Yukhnovsky District & 17.86 & -14.28 & -3.57 & 10.71 & 3.57 \\
\hline Borovsky District & & & & & \\
\hline
\end{tabular}




\begin{tabular}{|c|c|c|c|c|c|}
\hline Lyudinovsky District & 3.33 & -3.33 & 10 & 6.67 & -3.33 \\
\hline Babyninsky District & 25 & -16.67 & -4.17 & 0 & 4.17 \\
\hline Kaluga & 3.57 & 0 & 0 & 0 & -3.57 \\
\hline Tarussky District & 18.75 & -12.5 & -9.38 & 0 & -3.13 \\
\hline Kozelsky District & 0 & -7.69 & 3.85 & 7.69 & -3.85 \\
\hline Kaluga Oblast & 7.69 & -11.54 & 0 & 7.69 & -11.54 \\
\hline Zhizdrinsky District & 0 & -11.11 & 0 & 0 & 0 \\
\hline Ferzikovsky District & 2.94 & -5.88 & -2.94 & -2.94 & -2.94 \\
\hline Sukhinichsky District & -3.57 & -10.71 & -3.57 & -7.14 & 10.71 \\
\hline Dzerzhinsky District & 7.14 & -17.86 & -3.57 & -2.94 & 0 \\
\hline $\begin{array}{c}\text { Spas-Demensky } \\
\text { District }\end{array}$ & -3.57 & -10.71 & 0 & -10.71 & -3.57 \\
\hline Medynsky District & -6.25 & -15.63 & -9.38 & 3.13 & -3.13 \\
\hline $\begin{array}{c}\text { Khvastovichsky } \\
\text { District }\end{array}$ & -8.33 & -11.11 & -13.89 & 2.78 & -2.78 \\
\hline Peremyshlsky District & -10.53 & -18.42 & -5.26 & -5.26 & -2.63 \\
\hline Baryatinsky District & -3.33 & -13.33 & -10 & -23.33 & 3.57 \\
\hline
\end{tabular}

Note: bold text indicates areas with positive growth rates, italics indicate negative ones.

- In Obninsk, Zhukovsky, Ulyanovsky, and Iznoskovsky Districts, all factors showed a positive trend and had a positive impact on the socio-economic development sustainability. Whereas in the Spas-Demensky and Peremyshlinsky Districts all factors showed a negative trend and had an adverse effect on the socio-economic development sustainability.

- Sukhinichesky and Baryatinsky Districts have positive growth rates in socio-economic development sustainability due to digital environment development. However, this did not prevent the overall reduction of the level of development due to the negative impact of all the other factors.

- The low level of development of the digital environment had an adverse effect on the socio-economic development sustainability in 12 districts of the region.

The obtained results indicate that digitalization is not a driving factor in the socio-economic development of municipal districts and city districts of Kaluga Oblast. All of the above confirms the need to intensify the efforts of state and municipal authorities to develop the digital environment of the region.

\section{ACKNOWLEDGMENTS}

The practical value of the results of this study is the possibility of using the given conclusions and recommendations for making reports on the implementation of the national program "Digital Economy of the Russian Federation" for the Ministry of Economic Development of the Kaluga Oblast.

The reported research was funded by the Russian Foundation for Basic Research, grant № 19-410-400002 "The modeling of the economic-geographical and demographic factors of socio-economic development and projecting the strategic regional goals under digital environment development (illustrated by the case of Kaluga Oblast) ».

\section{REFERENCES}

[1] Index of electronic society// [Electronic resource]. URL:

https://d1iydh3qrygeij.cloudfront.net/Media/Default/lan ding-pages/Digital_society_index.pdf. (Accessed date: January 10, 2020)

[2] Information society: main characteristics of the subjects of the Russian Federation. Statistical compendium. 2018. [Electronic resource]. - URL: https://issek.hse.ru/data/2019/01/21/1147365079/io_reg .PDF (Accessed date: January 10, 2020).

[3] The official website of the Russian Federal State Statistics Service. [Electronic resource]. - URL: http://old.gks.ru/wps/wcm/connect/rosstat main/rosstat/ $\underline{\text { ru/statistics/science and innovations/it technology/\# }}$

[4] Negroponte, N. (1995). Being Digital. - New York : Alfred A. Knopf, 1995. - 243 p.

[5] D. Tapscott, (1997). The digital economy: promise and peril in the age of networked intelligence. NewYork: McGrawHill. ISBN 0-07-063342-8.

[6] D. Hamilton, (2017) The Transatlantic Digital Economy 2017: How and Why it Matters for the United States, Europe and the World. Washington, DC: Center for Transatlantic Relations, 2017.

[7] Program "Digital Economy of the Russian Federation": approved by the decree of the Government of the Russian Federation No. 1632-R of July 28, 2017.// http://government.ru/docs/28653// 
[8] M. Yu. Arkhipova, V. P. Sirotin, (2019). Development of digital technologies in Russia: regional aspects. Ekonomika regiona [Economy of region], $15(3), 670-683$

[9] L. G. Batrakova, (2019)/ Development of digital economy in the subjects of Russia // Socio-political research. - 2019. - No. 1. P. 51-64.

[10] Nikolaj Dmitrievich Bublik, Irina Ivanovna Lukina, Denis Valeryevich Chuvilin, Timur Ajratovich Shafikov, Razilja Fanuzovna Junusova (2018).The development of the digital economy in the regions of Russia: problems and opportunities (on the example of the Republic of Bashkortostan). Regional economy and management: electronic scientific journal. No. 1 (53). Art. \#5313. Date issued: 2018-03-15. Available at: https://eee-region.ru/article/5313/.

[11] S. A. Grachev, O. A. Donichev, (2019). Digital technologies as regions innovative development factor. 1st International Scientific Conference "Modern Management Trends and Digital Economy: from Regional Development to Global Economic Growth (MTDE 2019) Series of books: AEBMR-Advances in Economics Business and Management Research Volume: 81 Pp. 145-149.

[12] Golova, I. M., Sukhovey, A. F. (2018). Threats to the Security of Innovative Regional Development in a Digital Society. Ekonomika regiona [Economy of Region], 14(3), 987-1002/.

[13] T. V. Kramin, A. R. Klimanova, (2019). Development of digital infrastructure in the Russian regions. Terra Economicus, 17(2), 60-76. DOI: 10.23683/20736606-2019-17-2-60-7.

[14] S. Zemtsov, V. Barinova, R. Semenova (2019). The Risks of Digitalization and the Adaptation of Regional Labor Markets in Russia. Foresight and STI Governance, vol. 13, no 2, pp. 84-96. DOI: 10.17323/2500-2597.2019.2.84.96.

[15] Anna Tikhonova, Nadezhda Melnikova, Nadezhda Vishnevskaya, (2018). Readiness of Russian regions to digitize the economy. ECONOMIC ANNALS-XXI Volume: 174 Issue: 11-12 Pages: 16-21
[16] I. M. Syroezhin, (1980). Improving the system of indicators of efficiency and quality. Moscow. Economics, 1980.

[17] N.N. Zakharchenko, (1993). Economic measurement: theory and methods. Saint Petersburg: Saint Petersburg State University of Economics and Finance press.

[18] A.V. Zavgorodniaia, (1999). Diagnosis and modelling of the environment of the firm. Saint Petersburg: Saint Petersburg State University of Economics and Finance press.

[19] R.L. Zhambekova, (2000). The methodology of the system of economic diagnostics of the enterprise: the Dissertation on competition of a scientific degree of the doctor of economic Sciences: 08.00.05. Saint Petersburg State University of Economics and Finance.

[20] S.G. Svetunkov, A.V. Zagranovskaia \& I.S. Svetunkov, (2012). The rating of development of regions and the dynamics of their socio-economic status. Complex-valued analysis and modeling of uneven socio-economic development of regions of Russia.

www.sergey.svetunkov.ru/economics/complex/MD201 2

[21] T. A. Burtseva, (2009). Indicative model of monitoring the investment attractiveness of the region. Statistics problems, 2009 . - No. 6, P. 37-45.

[22] T. A. Burtseva, (2015). Methodology of statistical research of investment attractiveness of Russian regions. Statistics problems , 2015 - No. 1, P.29-45.

[23] T. Burtseva, (2000). Statistical Research of Investment Appeal of Russian Regions //Statistics Growing Data Sets and Growing Demand for Statistics ISBN 978-1-78984-396-5: URL: http://mts.intechopen.com/articles/show/title/statisticalresearch-of-investment-appeal-of-russian-regions (DOI: 10.5772/intechopen.75465).

[24] T. A. Burtseva, N. Y. Chausow, (2016). Satisfaction of scorecard balance //IEJME: Mathematics Education. 2016. Vol. 11. No. 9. Pp. 3361-3370. 